\title{
The yield and yield-character variability of traditional leafy-crop Cucumis africanus in response to variation in irrigation intervals and NPK fertilizer rates
}

\author{
R. J. Nkgapele \& M. S. Mphosi \\ Limpopo Agro-food Technology station, \\ School of Agriculture and Environmental Sciences, \\ University of Limpopo, Republic of South Africa
}

\begin{abstract}
An experiment laid out in a split-plot design and replicated three times was conducted to study the effects of irrigation frequency (at 2, 4 and 6 day intervals) and NPK fertilizer rates (0 Kg NPK ha-1, 60-40-20 kg NPK ha-1, 120-80-40 kg NPK ha-1 and 180-120-60 kg NPK ha-1) on biomass yield, harvest index (HI), productivity scores, and leaf and non-leaf yield characters of Cucumis africanus. A six day irrigation interval and 60-40-20 $\mathrm{kg} \mathrm{NPK} \mathrm{ha}^{-1}$ application rate produced significantly higher $(\mathrm{P}<0.05)$ fresh vegetative matter, while apparent and structural HI's were pronounced when $120-80-40 \mathrm{~kg} \mathrm{NPK} \mathrm{ha}^{-1}$ was applied. The highest productivity scores were produced by moderate irrigation frequency of four day intervals while applying nutrient mixtures at the rate of $120-80-40 \mathrm{~kg}$ $\mathrm{NPK} \mathrm{ha}^{-1}$. In conclusion, the study results depict that Cucumis myriocarpus as a dual purpose, leafy vegetable and ethnobotanical crop, can grow with minimal irrigation water application and a moderate supply of nutrients to produce adequate biomass yields for rural households in the Limpopo Province.
\end{abstract}

Keywords: harvest index, productivity score, leaf length, ethnobotanicals.

\section{Introduction}

Wild-watermelon, Cucumis africanus, a member of the family cucurbitaceae, whose fresh young leaves of the plant are eaten as a pot herb by many people in the rural communities of South Africa. Other research workers found that the 
leaves are rich in calcium, iron, nicotinic acid and vitamin C. Harvesting for leafy vegetable is usually carried out in the morning to maintain the full rigidity of the leaves and other fleshy parts of the plant. In South African traditional medicine the roots, shoots or fruits of $C$. africanus is used as an emetic, purgative or enema for various ailments. The boiled leaf is used as a poultice and it is also reported that the plant is useful in animal medicine [1].

Considering the growing problem of human population explosion and poor nutrition of foods exhibited among developing countries, the use of indigenous leafy vegetable species as high-mineral and vitamin source, as well as high-quality ethnobotanical linctus producer merits greater research [2]. As important sources of Vitamin A and other micronutrients indigenous leafy crops including C. africanus deserve pride in the rural economy, laboratory and trial fields [3]. Successful indigenous leafy-vegetable technology and transfer into conventional farming system depends on the species potential to germinate and emerge in the given soil physical and chemical conditions, as well as the ability of the seedlings to grow and develop [4]. Seedling growth covers the period in the life cycle of the plant, from emergence of the radicle through the seed coat until the appearance of enough green leaves to make the plant independent of stored energy $[5,6]$.

Dry matter partitioning is the end result of a coordinated set of transport and metabolic processes governing the flow of assimilates from source organs via a transport path to sink organs [7]. Gardner et al. [8] refer to the analysis of biomass distribution to different plant fractions as an important tool in order to understand the physiological principles and processes underlying the portioning of minerals and photosynthetic by-products to the nutritionally and economically significant harvestable plant fractions.

Roots are dependent on shoots for carbohydrates, growth regulators, and some other organic compounds and Shoots are dependent on roots for growth regulators such as abscisic acid, cytokinins and gibberellins [9]. Severe reduction in leaf area by pruning, insect defoliation, grazing, or diversion of food into fruit and seed production is likely to reduce the root growth. In a similar pattern, damage to root system will reduce water and mineral absorption, which in turn inhibits shoot growth [10].

The Root/shoot a ratio which is the relationship between above- and belowground biomass gives an indication of the functional, hormone-mediated equilibrium that governs the partitioning of assimilates between roots and shoots which know at the core of most models of plant growth [11]. High root/shoot ratios indicate that the plant is partitioning more assimilates to the roots, while lower ones indicate the opposite. There is a pronounced interdependence of roots and shoots and it is suggested that there might be some optimum ratio of roots to shoots [12]. However, root-shoot ratios vary widely among species, with age, and with environmental conditions. These variations results in part from the wide variations in water supply and other environmental factors to which plants often are subjected during a particular growing season, as well as to genetic variations among plants such as grasses and root crops. Perhaps the root-shoot ratio should be considered in terms of root and leaf surface, but it is difficult to measure root surface [13-15]. 
The current study pursues to evaluate and determine agronomic performance of traditional leafy-vegetable and ethnobotanical crop Cucumis africanus in terms of biomass yield, biomass partitioning to plant fractions and root/shoot ratios as influenced by irrigation water application frequency and NPK fertilizer application rate under greenhouse regime.

\section{Materials and methods}

\subsection{Site specification}

A greenhouse experiment was conducted at Horticultural Research Facility of University of Limpopo, Limpopo Province, South Africa (23⒌'10', S; 2944'15', E) during the 2009-2010 growing season. Ambient day/night temperatures averaged $28 / 21^{\circ} \mathrm{C}$, with maximum temperatures controlled using thermostatically-activated fans.

\subsection{Experimental layout and treatments}

The experiment was laid out in a split-plot design arrangement and replicated three times. Three irrigation intervals, namely, 2, 4 and 6 days, were accorded as main plots. During each irrigation interval, $1000 \mathrm{ml}$ tap-water was applied per pot. Irrigation water application treatments were applied seven days after transplanting. NPK application rates of $0 \mathrm{Kg}$ NPK ha-1, 60-40-20 kg NPK ha-1, 120-80-40 kg NPK ha ${ }^{-1}$ and 180-120-60 $\mathrm{kg} \mathrm{NPK} \mathrm{ha}^{-1}$ were accorded to sub-plot treatments.

\subsection{Experimental protocol}

Cucumis africanus seedlings were raised in seedling trays using thirty-cmdiameter plastic pots, filled with $10 \mathrm{~L}$ steam-pasteurised sand and Hygromix $(3: 1 \mathrm{v} / \mathrm{v})$, which were placed on greenhouse benches at $0.5 \mathrm{~m}$ inter-row and $0.6 \mathrm{~m}$ intra-row spacing. Uniform three-week-old Cucumis africanus seedlings were transplanted to the pots one day after irrigating the growing medium to field capacity. NPK fertilizer $(3: 2: 1)$ was given in split doses. First dose was applied at transplanting of seedlings into $30 \mathrm{~cm}$ plastic pots, while the remaining dose was applied 20 days after the first dose.

\subsection{Data collection and analysis}

At 60 days after transplanting (60 DAT) plants were harvested. Above- and belowground plant parts were separated into roots, stems and leaves. Sample pots were emptied and roots carefully separated from the soil mixture using a gentle stream of water. Canopy area was measured using canopy area meter (LI-3100C, LI-COR, Bioscience, Lincoln, NE 68504 USA) and then fresh and dry root, stem 
and leaf weights were determined using a standard balance scale. The collected data was recorded for the following leaf yield characters: leaf biomass, shoot biomass, leaf length, Leaf width and canopy area; non-leaf yield characters: root biomass, stem biomass, main vine length, lateral vine length, lateral vine number and root length; and ratios of plant fractions: root/stem, root/leaf, root/shoot and leaf/stem.

The data of all the above mentioned parameters were individually subjected to the analysis of variance techniques using Statistix 8.1 software (Statistix, Analytical Software, Statistix; Tallahassee, FL, USA, 1985-2003). Mean comparisons were done using least significance difference (LSD) at 0.05 level of probability $[16,17]$. When treatments were significant sum of squares were partitioned to determine the percentage contribution of source of variation to the total treatment variation [18].

\section{Results}

\subsection{Biomass yield and harvest indexes}

Biomass yield: Biomass yield exhibited highly significant $(\mathrm{P}<0.01)$ variances in response to irrigation interval and NPK fertilizer application rate treatments. The highest yield resulted when C. africanus plants were subjected to six day irrigation interval and fertilizer rate of 60-40-20 kg NPK ha ${ }^{-1}$, and was $201 \%$ higher than the lowest biomass yield. Average biomass yield ranged from 1662 to $2079 \mathrm{~kg} \mathrm{ha}^{-1}$ and were correspondingly $10.1 \%$ lower and $12.4 \%$ higher than average biomass yield across the treatments (Table 1). Application of NPK fertilizer contributed a highly significant $(\mathrm{P}<0.01) 59.2 \%$ of total treatment variation across the treatment applied to the experimental units (Table 2).

Apparent harvest index $\left(\mathrm{HI}_{\mathrm{App}}\right)$ : highly significant $(\mathrm{P}<0.01)$ differences were observed on $\mathrm{HI}_{\text {App }}$ as a factor of NPK fertilizer application which contributed $33.3 \%$ of total treatment variation across the treatments (Table 2). The high percentage of $\mathrm{HI}_{\mathrm{App}}$ was achieved when $C$. africanus plants were exposed to irrigation episodes of six day interval and applying fertilizer at the rate $60-40-20$ $\mathrm{kg} \mathrm{NPK} \mathrm{ha}{ }^{-1}$. The highest $\mathrm{HI}_{\mathrm{App}}$ was correspondingly 32.7 and $22.6 \%$ higher than the lowest and average $\mathrm{HI}_{\mathrm{App}}$ across the irrigation interval and NPK rate treatments (Table 1).

Structural harvest index $\left(\mathrm{HI}_{\mathrm{Str}}\right)$ : $\mathrm{HI}_{\mathrm{Str}}$ displayed highly significant $(\mathrm{P}<0.01)$ vagaries as a result of NPK fertilizer application while irrigation interval and treatment interaction where non-significant $(\mathrm{P}>0.05)$. NPK fertilizer rate accounted for $39 \%$ of the total treatment variation in the study (Table 2). The highest $\mathrm{HI}_{\text {Str }}$ was respectively 93.7 and $34.8 \%$ higher than the lowest and average $\mathrm{HI}_{\text {str }}$ across the irrigation interval and NPK rate treatments and was achieved when plants were irrigated at six day interval with fertilizer applied at $60-40-20 \mathrm{~kg} \mathrm{NPK}$ $\mathrm{ha}^{-1}$ rate (Table 1). 
Table 1: Fresh biomass yield, apparent and structural harvest index and productivity scores of Cucumis africanus as affected by irrigation interval and NPK application rate during the 2009/10 growing season.

\begin{tabular}{|l|l|l|l|l|l|}
\hline Interval & NPK rate & Biomass Yield & \multicolumn{2}{|c|}{ HI (\%) } & \\
\hline (days) & -------- & $\left(\mathrm{kg} \mathrm{ha}^{-1}\right)---------$ & Apparent & Structural & Prod. Score \\
\hline 2 & 0 & $929.0 \mathrm{c}$ & $47.9 \mathrm{ab}$ & $61.6 \mathrm{cde}$ & $716.7 \mathrm{fg}$ \\
\hline & $60-40-20$ & $2472.2 \mathrm{ab}$ & $50.6 \mathrm{ab}$ & $82.3 \mathrm{abc}$ & $1327.9 \mathrm{abc}$ \\
\hline & $120-80-40$ & $1941.4 \mathrm{abc}$ & $49.6 \mathrm{ab}$ & $75.6 \mathrm{bcd}$ & $1257.1 \mathrm{abc}$ \\
\hline & $180-120-60$ & $1879.6 \mathrm{abc}$ & $47.3 \mathrm{ab}$ & $69.9 \mathrm{cde}$ & $1212.0 \mathrm{abcd}$ \\
\hline 4 & 0 & $942.9 \mathrm{c}$ & $45.5 \mathrm{bc}$ & $58.8 \mathrm{de}$ & $771.3 \mathrm{efg}$ \\
\hline & $60-40-20$ & $1757.7 \mathrm{abc}$ & $48.8 \mathrm{ab}$ & $70.2 \mathrm{cde}$ & $1188.5 \mathrm{bcde}$ \\
\hline & $120-80-40$ & $2375.0 \mathrm{ab}$ & $50.9 \mathrm{ab}$ & $73.6 \mathrm{bcd}$ & $1627.3 \mathrm{a}$ \\
\hline 6 & $180-120-60$ & $1572.5 \mathrm{bc}$ & $49.9 \mathrm{ab}$ & $68.5 \mathrm{cde}$ & 1123.7 \\
\hline & 0 & $1489.2 \mathrm{bc}$ & $40.4 \mathrm{c}$ & $50.6 \mathrm{e}$ & $657.8 \mathrm{~g}$ \\
\hline & $60-40-20$ & $2797.8 \mathrm{a}$ & $50.8 \mathrm{ab}$ & $91.1 \mathrm{ab}$ & $1369.2 \mathrm{abc}$ \\
\hline & $120-80-40$ & $2267.0 \mathrm{ab}$ & $53.6 \mathrm{a}$ & $98.0 \mathrm{a}$ & $1557.9 \mathrm{ab}$ \\
\hline & $180-120-60$ & $1760.8 \mathrm{abc}$ & $47.6 \mathrm{ab}$ & $72.1 \mathrm{bcd}$ & $817.4 \mathrm{defg}$ \\
\hline
\end{tabular}

Column means with the same letter were not different at $5 \%$ level according to the LSD test. ns $=$ none significant.

Table 2: Analysis of variance for biomass yield, harvest index and productivity scores of Cucumis africanus as affected by irrigation interval and NPK application rate at late vegetative growth stage (60 DAT) during the 2009/10 summer growing season.

\begin{tabular}{|c|c|c|c|c|c|c|c|c|c|}
\hline \multirow{3}{*}{$\begin{array}{l}\text { Source of } \\
\text { variation }\end{array}$} & \multirow[t]{3}{*}{ Df } & \multicolumn{8}{|c|}{ Fresh biomass } \\
\hline & & \multicolumn{2}{|c|}{ Biomass yield } & \multicolumn{2}{|c|}{ Apparent HI } & \multicolumn{2}{|c|}{ Structural HI } & \multicolumn{2}{|c|}{ Productivity score } \\
\hline & & SS & $\%$ & SS & $\%$ & SS & $\%$ & SS & $\%$ \\
\hline Replicate (A) & 2 & 1124999 & 0.25 & 53.33 & 7.52 & 791.30 & 8.14 & 4989 & 0.10 \\
\hline Irrigation (B) & 2 & 4077998 & $0.89^{\mathrm{ns}}$ & 3.961 & $0.56^{\mathrm{ns}}$ & 554.09 & $5.70^{\mathrm{ns}}$ & 32523 & $0.66^{\mathrm{ns}}$ \\
\hline Error $\left(\mathrm{A}^{*} \mathrm{~B}\right)$ & 4 & 3260745 & 0.71 & 10.19 & 1.44 & 84.79 & 0.87 & 35160 & 0.72 \\
\hline NPK rate $(\mathrm{C})$ & 3 & $\begin{array}{l}27020000 \\
8\end{array}$ & $59.2 * * *$ & 236.1 & $33.3 * * *$ & 3777.3 & $38.9 * * *$ & 2956239 & $60.1 * * *$ \\
\hline $\mathrm{B} * \mathrm{C}$ & 6 & 49360007 & $10.8^{\mathrm{ns}}$ & 128.7 & $18.2^{\mathrm{ns}}$ & 1352.2 & $13.9^{\mathrm{ns}}$ & 526243 & $10.7^{\mathrm{ns}}$ \\
\hline $\begin{array}{l}\text { Error } \\
(A * B * C)\end{array}$ & 18 & $\begin{array}{l}12850000 \\
8 \\
\end{array}$ & 28.1 & 276.6 & 39.0 & 3162.6 & 32.5 & 1361188 & 27.7 \\
\hline Total & 35 & $\begin{array}{l}45652376 \\
5\end{array}$ & 100 & 708.9 & 100 & 9722.3 & 100 & 4916342 & 100 \\
\hline
\end{tabular}

*** Significant $(\mathrm{P}<0.01)$, ** Significant $(\mathrm{P}<0.05), \mathrm{Df}=$ degree of freedom, $\mathrm{SS}=$ sum of squares, ns $=$ non-significant.

\subsection{Vegetative yield characters}

\subsubsection{Leaf yield characters}

Leaf-based vegetative yield characters of $C$. africanus were immensely influenced $(\mathrm{P}<0.01)$ by the interaction between irrigation interval and NPK fertilizer application rate. Subsequently, irrigation significantly $(\mathrm{P}<0.05)$ influences leaf area and leaf length while leaf with was not affect (Table 3). The interaction between irrigation interval and NPK fertilizer rate accounted for 39, 42 and 27\% 
of total treatment variation in leaf area, leaf length and leaf width, respectively. Contrariwise, irrigation interval contributed correspondingly 20 and $21 \%$ to total treatment variation in leaf area and leaf length while leaf with was not significant (Table 3). Leaf area, leaf width and leaf length exhibited the widest spread and longest length when four day irrigation interval and 60-40-20 kg NPK ha-1 fertilizer application rate were applied to $C$. africanus plants (Table 4). The widest leaf area and width were and \% wider narrowest and width, respectively, while the longest leaf length was \% longer than the shortest length.

Table 3: Analysis of variance for leaf yield characters of Cucumis africanus as affected by irrigation interval and NPK application rate at late vegetative growth stage (60 DAT) during the 2009/10 summer growing season.

\begin{tabular}{|c|c|c|c|c|c|c|c|}
\hline \multirow{3}{*}{$\begin{array}{l}\text { Source of } \\
\text { variation }\end{array}$} & \multirow[t]{3}{*}{ Df } & \multicolumn{6}{|c|}{ Yield characters } \\
\hline & & \multicolumn{2}{|c|}{ Leaf area } & \multicolumn{2}{|c|}{ Leaf width } & \multicolumn{2}{|c|}{ Leaf length } \\
\hline & & SS & $\%$ & SS & $\%$ & SS & $\%$ \\
\hline Replicate (A) & 2 & 28753 & 2.43 & 107.3 & 7.57 & 0.06 & 0.06 \\
\hline Irrigation (B) & 2 & 238092 & $20.1 * *$ & 80.49 & $5.68^{\mathrm{ns}}$ & 20.7 & $20.7 * *$ \\
\hline Error $(\mathrm{A} * \mathrm{~B})$ & 4 & 102885 & 8.70 & 49.16 & 3.47 & 5.79 & 5.80 \\
\hline NPK rate $(\mathrm{C})$ & 3 & 52294 & $4.42^{\mathrm{ns}}$ & 41.88 & $2.96^{\mathrm{ns}}$ & 4.91 & $4.92^{\mathrm{ns}}$ \\
\hline $\mathrm{B} * \mathrm{C}$ & 6 & 464511 & $39.3 * * *$ & 380.4 & $26.8 * * *$ & 41.5 & $41.6^{* * *}$ \\
\hline Error $(A * B * C)$ & 18 & 296208 & 25.0 & 757.8 & 53.5 & 26.8 & 26.9 \\
\hline Total & 35 & 1182743 & 100 & 1417 & 100 & 99.8 & 100 \\
\hline
\end{tabular}

*** Significant $(\mathrm{P}<0.01),{ }^{* *}$ Significant $(\mathrm{P}<0.05), \mathrm{Df}=$ degree of freedom, $\mathrm{SS}=$ sum of squares, ns $=$ non-significant.

Table 4: Leaf yield characters of Cucumis africanus as affected by irrigation interval and NPK application rate at 60 days after transplanting during the $2009 / 10$ growing season.

\begin{tabular}{|c|c|c|c|c|}
\hline \multirow{2}{*}{$\begin{array}{l}\text { Irrigation } \\
\text { Frequency }\end{array}$} & \multirow[b]{2}{*}{ NPK rate } & \multicolumn{3}{|c|}{ Leaf yield characters } \\
\hline & & Leaf area & Leaf length & Leaf width \\
\hline (days) & $\mathrm{kg} \mathrm{ha}^{-1}$ & $\mathrm{~mm}^{2}$ & \multicolumn{2}{|l|}{$\mathrm{mm}$} \\
\hline \multirow[t]{4}{*}{2} & 0 & $501.6 \mathrm{~b}$ & $40.6 \mathrm{ab}$ & $12.72 \mathrm{de}$ \\
\hline & $60-40-20$ & $529.2 \mathrm{ab}$ & $40.3 \mathrm{ab}$ & $13.62 \mathrm{cde}$ \\
\hline & $120-80-40$ & $542.2 \mathrm{ab}$ & $41.3 \mathrm{ab}$ & $13.12 \mathrm{cde}$ \\
\hline & $180-120-60$ & $557.3 \mathrm{ab}$ & $47.9 \mathrm{a}$ & $11.62 \mathrm{e}$ \\
\hline \multirow[t]{4}{*}{4} & 0 & $569.6 \mathrm{ab}$ & $38.2 \mathrm{ab}$ & 12.16de \\
\hline & $60-40-20$ & $655.6 \mathrm{a}$ & $46.8 \mathrm{a}$ & $16.87 \mathrm{a}$ \\
\hline & $120-80-40$ & $585.1 \mathrm{ab}$ & $38.9 \mathrm{ab}$ & $14.39 \mathrm{bcd}$ \\
\hline & $180-120-60$ & $535.5 \mathrm{ab}$ & $34.2 \mathrm{~b}$ & $15.22 \mathrm{bc}$ \\
\hline \multirow[t]{4}{*}{6} & 0 & $486.2 b$ & $37.0 \mathrm{ab}$ & $13.72 \mathrm{cde}$ \\
\hline & $60-40-20$ & $525.5 \mathrm{ab}$ & $36.5 \mathrm{ab}$ & $15.02 \mathrm{bc}$ \\
\hline & $120-80-40$ & $594.1 \mathrm{ab}$ & $40.3 \mathrm{ab}$ & $14.72 \mathrm{bcd}$ \\
\hline & $180-120-60$ & $561.7 \mathrm{ab}$ & $41.7 \mathrm{ab}$ & $13.52 \mathrm{cde}$ \\
\hline
\end{tabular}

Column means with the same letter were not different at $5 \%$ level according to the LSD test, ns $=$ none significant. 


\subsubsection{Non-leaf yield characters}

Non-leaf yield characters of lateral vine length displayed highly $(\mathrm{P}<0.01)$ differences in response to NPK fertilizer application rate and the interaction between irrigation interval and NPK fertilizer rate. In addition, significant $(\mathrm{P}<0.05)$ responses to NPK fertilizer application rate were shown by both number of lateral vines per plant and main vine length while on the contrary lateral vine length responded significantly to irrigation interval (Table 5). NPK application rate accounted for 28 and $35 \%$ of the total variation for main vine and lateral, respectively, the interaction between irrigation interval and NPK fertilizer rate contributed for correspondingly 38 and $19.3 \%$ to total treatment variation on lateral vine length and lateral vine number. The longest main vine and lateral vine were 242 and 56\% longer than shortest characters, respectively (Table 6).

Table 5: Analysis of variance for non-leaf yield characters of Cucumis africanus as affected by irrigation interval and NPK application rate at late vegetative growth stage (60 DAT) during the 2009/10 summer growing season.

\begin{tabular}{|l|l|l|l|l|l|l|l|}
\hline \multirow{2}{*}{$\begin{array}{l}\text { Source of } \\
\text { variation }\end{array}$} & \multirow{2}{*}{ Df } & \multicolumn{2}{|l|}{ Yield characters } \\
\cline { 3 - 8 } & & Main vine length & \multicolumn{2}{|l|}{ Lateral vine length } & \multicolumn{2}{l|}{ Lateral vine no. } \\
\cline { 3 - 8 } & & SS & $\%$ & SS & $\%$ & SS & $\%$ \\
\hline Replicate $(\mathrm{A})$ & 2 & 4640 & 5.47 & 110.0 & 1.02 & 0.13 & 0.56 \\
\hline Irrigation $(\mathrm{B})$ & 2 & 6536 & $7.71^{\mathrm{ns}}$ & 676.4 & $6.30 * *$ & 2.54 & $10.9^{\mathrm{ns}}$ \\
\hline Error $\left(\mathrm{A}^{*} \mathrm{~B}\right)$ & 4 & 1553 & 1.83 & 31.03 & 0.29 & 0.58 & 2.48 \\
\hline NPK rate $(\mathrm{C})$ & 3 & 23842 & $28.1^{* *}$ & 3754 & $35.0 * * *$ & 1.00 & $4.28^{\mathrm{ns}}$ \\
\hline $\mathrm{B} * \mathrm{C}$ & 6 & 12039 & $14.2^{\text {ns }}$ & 4063 & $38.0 * * *$ & 4.50 & $19.3^{* *}$ \\
\hline Error $\left(\mathrm{A}^{*} \mathrm{~B}^{*} \mathrm{C}\right)$ & 18 & 36215 & 42.7 & 2100 & 19.5 & 14.6 & 62.5 \\
\hline Total & 35 & 84825 & 100 & 10734 & 100 & 23.4 & 100 \\
\hline
\end{tabular}

*** Significant $(\mathrm{P}<0.01),{ }^{* *}$ Significant $(\mathrm{P}<0.05), \mathrm{Df}=$ degree of freedom, $\mathrm{SS}=$ sum of squares, ns $=$ non-significant.

Table 6: Non-leaf yield characters of Cucumis africanus as affected by irrigation interval and NPK application rate at late vegetative growth stage during the $2009 / 10$ season.

\begin{tabular}{|c|c|c|c|c|}
\hline Irrigation Interval & NPK rate & Main vine & Lateral vine & No. of vines \\
\hline (days) & $\left(\mathrm{kg} \mathrm{ha}^{-1}\right)$ & \multicolumn{2}{|c|}{---------- cm -------- } & \\
\hline \multirow[t]{4}{*}{2} & 0 & $82.63 \mathrm{c}$ & 22.94 & $2.27 \mathrm{ab}$ \\
\hline & $60-40-20$ & $166.9 \mathrm{ab}$ & 54.60 & $2.60 \mathrm{ab}$ \\
\hline & $120-80-40$ & $118.3 \mathrm{abc}$ & 62.27 & $2.94 \mathrm{ab}$ \\
\hline & $180-120-60$ & $150.6 \mathrm{abc}$ & 78.94 & $1.94 \mathrm{~b}$ \\
\hline \multirow[t]{4}{*}{4} & 0 & $76.83 \mathrm{c}$ & 49.50 & $3.29 \mathrm{ab}$ \\
\hline & $60-40-20$ & $161.2 \mathrm{ab}$ & 46.17 & $2.95 \mathrm{ab}$ \\
\hline & $120-80-40$ & $177.5 \mathrm{a}$ & 46.50 & $2.29 \mathrm{ab}$ \\
\hline & $180-120-60$ & $100.5 \mathrm{bc}$ & 72.83 & $2.95 \mathrm{ab}$ \\
\hline \multirow[t]{4}{*}{6} & 0 & $78.25 \mathrm{c}$ & 34.08 & $2.71 \mathrm{ab}$ \\
\hline & $60-40-20$ & $108.9 \mathrm{abc}$ & 62.42 & $3.71 \mathrm{a}$ \\
\hline & $120-80-40$ & $116.3 \mathrm{abc}$ & 41.75 & $2.71 \mathrm{ab}$ \\
\hline & $180-120-60$ & $92.58 \mathrm{bc}$ & 39.75 & $3.38 \mathrm{ab}$ \\
\hline
\end{tabular}

Column means with the same letter were not different at $5 \%$ level according to the LSD test, ns $=$ none significant. 


\section{Discussion}

Adequate biomass supply of indigenous crops such as $C$. africanus are required for both consumption as a leafy vegetable and use as ethnobotanicals in many rural areas of developing regions $[19,20]$. The results of the study show that by applying intermediate irrigation frequency and NPK rate substantially high amounts of fresh and dry biomass yields of $C$. africanus that are required by the rural populace can be achieved. Consequently, with the advent of escalating water shortages [21] and lack of inorganic fertilizer-inputs supplies [22] in rural communities it can be deduced from the above findings that smallholder farmers can produce $C$. africanus with infrequent irrigation episodes and minimal nutrient inputs applications. An additional benefit to diets of indigenous leafy vegetables consumers is that it is reported by several workers that they can contribute with significant amounts of vitamins and minerals, and are especially excellent sources of protein, carotene, iron and ascorbic acid [23, 24]; an attribute that can greatly assist in the fight against the hidden hunger prevalent in many rural areas.

In our study partitioning of biomass to roots, stems and leaves, was found to be significantly influenced by irrigation frequency and NPK rate at intermediate levels of application. These results agrees with findings by several workers on other vegetable crops, Erdem et al. [25] in watermelon, Waseem et al. [26] in cucumber, Khan et al. [27] in bell pepper, van Averbeke and Juma [28] in Brassica rapa L. subsp. chinensis and Solanum retroflexum Dun. In contrast, Sensoy et al. [29] found good responses with treatments employing greatest frequency and quantity of irrigation in field-grown melon and Singh et al. [30] found that NPK dose above the recommended was required to minimize the adverse impacts of nutrient shortages in cropping systems.

In this study, highly significant $(\mathrm{P} \leq 0.05)$ variances were observed for root/shoot ratio. Applying irrigation at four day frequency and 60-40-30 NPK kg $\mathrm{ha}^{-1}$ rate produced the highest root/shoot ratio which was $92.98 \%$ higher than the lowest root/shoot ratio, an indication that in this treatment more assimilates where to the roots [31]. The lowest root/shoot ratio was given by irrigating on a six day frequency basis and applying 120-80-60 NPK kg ha-1 which supported production of above-ground portions as opposed to the below ones. Nonetheless, these treatments were not superior in terms of total and plant fraction biomass yield.

\section{Conclusions}

The results of the study showed significant influences that varying irrigation water application frequencies and NPK fertilizer application rates has on biomass yield and portioning, as well as the relationship between the above- and below-ground plant parts. The highest Cucumis africanus plant fraction harvest of stem $\left(61.73 \mathrm{~g} \mathrm{~m}^{-2}\right)$; leaf $\left(72.84 \mathrm{~g} \mathrm{~m}^{-2}\right)$ and shoot $\left(143.57 \mathrm{~g} \mathrm{~m}^{-2}\right)$ were obtained in the four day irrigation interval and fertilizer combination of $120-80-40 \mathrm{~kg} \mathrm{NPK} \mathrm{ha}^{-1}$ rate. A crop biomass harvest under these conditions produced fresh and dry biomass yields of correspondingly 2049.4 and $1506.2 \mathrm{~kg} \mathrm{ha}^{-1}$. 


\section{References}

[1] Botha, C.J. \& M.L. Perinth. Poisonous plants of veterinary and human importance in southern Africa. Journal of Ethnopharmacology 119: pp. 549-558, 2008.

[2] Tilman, D., Cassman, K.G., Matson, P.A., Naylor, R. \& Polasky, S. Agricultural sustainability and intensive production practices. Nature 418: pp. 671-677, 2002.

[3] Kano, Y., Goto, H., Fukuda, H. \& Ishimoto, K. Relationship between the Occurrence of Bitter Cucumber (Cucumis sativus L. cv. Kagafutokyuri) and Total Nitrogen, Nitrate-N, Amini Acid-N and Protein Content in the leaf and Peel. Journal of Japanese Society of Horticultural Science 70: pp. 438-442, 2001.

[4] Linnemann, A.R. \& Craufurd, P.Q. Effects of temperature and photoperiod on phenological development in three genotypes of bambara groundnut (Vigna subterranean). Annals of Botany 74: pp. 675-681, 1994.

[5] Salisbury, F.B. \& Ross, C.W. Plant Physiology, Wadsworth Publishing Company, Belmont, California, p. 126, 1992.

[6] Hopkins, W.G. Introduction to Plant Physiology. John Wiley \& sons, Inc.: New York, pp. 176-189, 1992.

[7] Freney, J.R. Strategies to Reduce Gaseous Emissions of Nitrogen from Irrigated Agriculture. Nutrient Cycling in Agroecosystems 48: pp. 155-160, 1997.

[8] Gardner, F.P., Pearce, R.B. \& Mitchell, R.L. Physiology of crop plants. Iowa state university press: Ames, pp. 187-209, 1985.

[9] Kramer, P.J. \& Boyer, J.S. Water Relations of Plants. Academic Press: London, pp. 158-184, 1995.

[10] Summerfield, R.J., Dart, P.J., Huxley, P.A., Eaglesham, A.R.J., Minchin, F.R. \& Day, J.M. Nitrogen nutrition of cowpea (Vignaunguiculata) I. Effects of applied nitrogen and symbiotic nitrogen fixation on growth and seed yield. Exp. Agric., 13: pp. 129-142, 1997.

[11] Hunt, R. Plant growth analysis: The rationale behind the use of the fitted mathematical function. Ann. Bot. 43: pp. 245-249, 1979.

[12] Stoskopf, N.C. Understanding crop production. Reston publishers Co., Inc.: Reston, Virginia, pp. 46-108, 1981.

[13] Tesar, M.B. Physiological basis of crop growth and development. American Soc. Agron., Inc. \& Crop Sci. Soc. America, Inc. Madison, Wisconsin, USA. pp. 134-160, 1984.

[14] Mulvane, R.L. Nitrogen - Inorganic Forms. In: Sparks D.L. (ed.). Methods of Soil Analysis. Part 3. Chemical Methods. Madison: WI, pp. 1-12, 1996.

[15] Klepper, B. Root-Shoot Relationships. In: Waisel, Y., Kafkafi, U. \& A. Eshel (eds.), Plant Roots: The Hidden Half. Marcel Dekker: New York, 1991.

[16] Gomez KA, Gomez AA (1984). Statistical procedures for agricultural research $2^{\text {nd }} e d$. John Wiley \& Sons, New York, pp. 146-184, 1984. 
[17] Kuehl R.O. Design of experiments: statistical principles of research design and analysis $2^{\text {nd }}$ ed. Duxbury press, New York, pp. 173-184, 2000.

[18] Little, T.M. \& Hills, F.J. Statistical methods in agricultural research, University of California, California, USA, p. 350, 1981.

[19] Jansen van Rensburg, W.S., van Averbeke, W., Slabbert, R., Faber, M., van Jaarsveld, P., van Heerden, I., Wenhold, F. \& Oelofse, A. African leafy vegetables in South Africa. Water SA, 33 (3), pp. 317-326, 2007.

[20] Ndlovu, J. \& Afolayan, A.J. Nutritional analysis of the South African wild vegetable Corchorusolitorius L. Asian J. Plant Sci., pp. 1-4, 2008.

[21] Auwalu, B.M. \& Babatunde, F.E. Analysis of growth, yield and fertilization of vegetable Sesame (Sesamum radiatum Schum). J. plant Sci., 2(1): pp. 108-112, 2007.

[22] Atta, S., Seyni, H.H., Bakasso, Y., Sarr, B., Lona, I. \& Saadou M. Yield character variability in Roselle (Hibiscus sabdariffa L.). Afr. J. Agric. Res., 6(6): pp. 1371-1377, 2011.

[23] Van Soest, P.J., Use of detergents in the analysis of fibrous feeds, II: A rapid method for the determination of fiber and lignin. Journal of Association of Office of Agricultural Chemistry, 46: pp. 829-835, 1963.

[24] Luyen, L.T., \& Preston, T. R. Effect of level of urea fertilizer on biomass production of water spinach (Ipomoea aquatica) grown in soil and in water. Livestock Research for Rural Development, 16, 2004.

[25] Erdem, Y., Yüksel, A.N. \& Orta, A.H. The effects of deficit irrigation on watermelon yield, water use and quality characteristics. Pakistan J. Bio. Sci., 4(7): pp. 785-789, 2001.

[26] Waseem, K., Kamran, Q.M. \& Jalani, M.S. Effect of different nitrogen levels on growth and yield of cucumber (Cucumis sativus L.). Journal of Agricultural Research, 46(3), pp. 259-266, 2008.

[27] Khan MH, Chattha T.H. \& Saleem N. (200). Influence of different irrigation intervals on growth and yield of bell pepper (Capsicum Annuum Grossum Group). Res. J. Agri. Bio. Sci., 1(2): pp. 125-128, 2005.

[28] Van Averbeke, W. \& Juma, K.A. The cultivation of Solanum retroflexum Dun. in Vhembe, Limpopo Province, South Africa. Proc. Int. Symp. on the Nutritional Value and Water Use of Indigenous Crops for Improved Livelihoods. 19-20 September 2006, University of Pretoria, Pretoria. [CD ROM]. The Centre for Nutrition, University of Pretoria, Pretoria. No page numbers.

[29] Sensoy, S., Ertek, A., Gedik, I. \& Kucukyumuk, C. Irrigation frequency and amount affect yield and quality of field-grown melon (Cucumis melo L.). Agric. W. Mngt., 88: pp. 269-274, 2007.

[30] Singh, S., Kumari, R., Agrawal, M. \& Agrawal, S.B. Modification of growth and yield responses of Amarantthus tricolor L. to sUV-B under varying mineral nutrient supply. Scientia Horticulturae, 120, pp. 173-180, 2009.

[31] Prusinkiewicz, P. Modeling plant growth and development. Current Opinion in Plant Biology, 7(1), pp. 79-83, 2004. 